\title{
Universiteit
}

Leiden

The Netherlands

\section{No more than a keg of beer. The coherence of German immigrant communities}

Schrover, Marlou; Feldman, David; Lucassen, Leo; Oltmer, Jochen

\section{Citation}

Schrover, M. (2006). No more than a keg of beer. The coherence of German immigrant communities. In D. Feldman, L. Lucassen, \& J. Oltmer (Eds.), Paths of integration. Migrants in Western Europe (1880-2004) (pp. 222-238). Amsterdam: Amsterdam University Press. Retrieved from https://hdl.handle.net/1887/19348

Version: $\quad$ Not Applicable (or Unknown)

License: $\quad$ Leiden University Non-exclusive license

Downloaded from: $\quad$ https://hdl.handle.net/1887/19348

Note: To cite this publication please use the final published version (if applicable). 


\section{Paths of Integration}




\section{IMISCOE (International Migration, Integration and Social Cohesion)}

IMISCOE is a European Commission-funded Network of Excellence of more than 350 scientists from various research institutes that specialise in migration and integration issues in Europe. These researchers, who come from all branches of the economic and social sciences, the humanities and law, implement an integrated, multidisciplinary and internationally comparative research programme that focuses on Europe's migration and integration challenges.

Within the programme, existing research is integrated and new research lines are developed that involve issues crucial to European-level policy-making and provide a theory-based design to implement new research.

The publication program of IMISCOE is based on five distinct publication profiles, designed to make its research and results available to scientists, policy makers and the public at large. High quality manuscripts written by IMISCOE members, or in cooperation with IMISCOE members, are published in these five series. An Editorial Committee coordinates the review process of the manuscripts. The five series are:

I. Joint Studies

2. Research

3. Reports

4. Dissertations

5. Training

More information on the network can be found at: www.imiscoe.org

IMISCOE Research includes publications resulting from research of IMISCOE members like research monographs and edited volumes. 


\title{
Paths of Integration
}

Migrants in Western Europe (1880-2004)

\author{
Leo Lucassen \\ David Feldman \\ Jochen Oltmer \\ (eds.)
}

IMISCOE Research

AMSTERdaM UNIVERSity PRESS 
Cover illustration: Hollandse Hoogte / Magnum

Cover design: Studio Jan de Boer bno, Amsterdam Lay-out: Fito Prepublishing, Almere

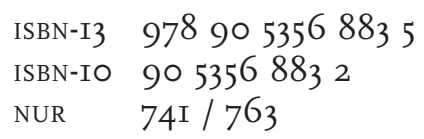

(C) Amsterdam University Press, Amsterdam 2006

All rights reserved. Without limiting the rights under copyright reserved above, no part of this book may be reproduced, stored in or introduced into a retrieval system, or transmitted, in any form or by any means (electronic, mechanical, photocopying, recording or otherwise) without the written permission of both the copyright owner and the author of the book. 


\section{Table of Contents}

Leo Lucassen, David Feldman and Jochen Oltmer

Immigrant Integration in Western Europe, Then and Now

PART I: THEN AND NOW: CONVERGENT COMPARISONS

Leo Lucassen

Poles and Turks in the German Ruhr Area: Similarities and Differences

Marie-Claude Blanc-Chaléard

Old and New Migrants in France: Italians and Algerians

Laure Teulières

Rural Dimensions at Stake: The Case of Italian Immigrants in

Southwestern France

Karen Schönwälder

Assigning the State its Rightful Place? Migration, Integration and the State in Germany

Jochen Oltmer

'To Live as Germans Among Germans.' Immigration and

Integration of 'Ethnic Germans' in the German Empire and the

Weimar Republic

Barbara Dietz

Aussiedler in Germany: From Smooth Adaptation to Tough

Integration

PART II: HERE AND THERE: DIVERGENT COMPARISONS

Dorota Praszałowicz

Polish Berlin: Differences and Similarities with Poles in the Ruhr Area, I860-1920

Mark-Anthony Falzon

A Passage from India: Trajectories of Economic Integration in London and Mediterranean Europe 
Laurence Brown

Afro-Caribbean Migrants in France and the United Kingdom

PART III: INSTITUTIONS AND INTEGRATION

Barbara Schmitter-Heisler

Trade Unions and Immigrant Incorporation: The US and

Europe Compared

Marlou Schrover

No More Than a Keg of Beer: The Coherence of German

Immigrant Communities

Thijl Sunier

Religious Newcomers and the Nation-State: Flows and Closures

Dorothee Schneider

American Immigrants Look at Their Americanisation

\section{PART IV: CONCLUSION}

Leo Lucassen, David Feldman and Jochen Oltmer

Drawing up the Balance Sheet 


\title{
No More than a Keg of Beer: The Coherence of German Immigrant Communities
}

\author{
Marlou Schrover
}

One evening in January I878, a special train ran between the Dutch cities of Amsterdam and Utrecht. ${ }^{\text {I }}$ The journey lasted an hour and the train stopped at every station in between. The local Utrecht newspaper had predicted that many people would take this train to attend a play at the German theatre in Amsterdam, and indeed 272 people did. It is not certain whether all of them went to the German theatre. There was also a circus in Amsterdam that same night. A fortnight later, another special train was announced in the Utrecht newspaper. This time the German theatre in Amsterdam premiered the play Freund Fritz, a comedy in three acts.

The German theatre in Amsterdam was a very active organisation. On March 29, I839, the opera Othello was performed. It was the $5^{\text {st }}$ performance at the theatre that season. There had been two productions every week, each time of a difference play or piece of music. Despite this enormous activity, the German theatre in Amsterdam had not been doing well financially. There was too little interest in the performances, and there were quarrels amongst the organisers. In I839, the director feared that his theatre, the only one in its kind in the Netherlands, would be forced to close. The Theatre Français did much better, despite the fact that the French immigrant community was only a fraction of the size of the German one. The French theatre, however, also attracted the Dutch elite, who admired French culture and enjoyed an evening of French entertainment. This elite did not appreciate German culture in a similar fashion. The German theatre however, managed to survive throughout the Igth century. The construction of a railway network contributed to its survival, because it enabled people from further away to travel to Amsterdam for an evening performance.

Utrecht did not have its own German theatre. The percentage of German immigrants in Amsterdam was not much larger than Utrecht's ( $2 \%$ in Amsterdam versus I.4 in Utrecht), but the actual population of immigrants in Amsterdam was larger. In I859, 5,286 Germans were living in Amsterdam. Apparently this number was not enough to maintain a theatre, but luckily it was supplemented by Germans from elsewhere as transportation improved. ${ }^{2}$ But the relatively modest size of the German immigrant community was not the only reason that the 
theatre was struggling. In I880, the American city of St. Louis had a German population that was ten times that of Amsterdam. St. Louis had over 300 active German clubs and societies, not counting the numerous church-related organisations. ${ }^{3}$ Yet, its theatre did not do well there either. ${ }^{4}$ The German language press of St. Louis praised the plays at the theatre endlessly, but like the theatre, the newspapers were struggling as well. The press and the theatre both had a vested interest in the preservation of the German language and its culture. The German language schools and German churches of St. Louis had similar interests, but did not do much better either. Language was clearly not what was keeping German communities together.

In I964, the Canadian researcher Raymond Breton believed that immigrant organisations increased the coherence within a group of immigrants because the creation of an immigrant organisation made the group's boundaries clearer. ${ }^{5}$ Critics of Breton's work pointed out that counting the number of organisations was not enough to measure the extent of a community's cohesion. ${ }^{6}$ Some organisations made strong demands on the loyalty of its members. Therefore, it was not only the number of organisations but also the character of the organisations that was important. ${ }^{7}$

Immigrant organisations are an interesting source of information about a group's identity or ethnicity. ${ }^{8}$ The character, size, and number of organisations indicate the extent to which immigrants want to profile themselves as being different, or are seen by others as being different. Immigrants set up organisations to create, express, and maintain a collective identity. ${ }^{9}$ By forming an organisation, immigrants fence off their ethnic identity from others. ${ }^{\text {IO }}$

It is generally accepted that 'groups' and 'ethnicity' are social constructs. ${ }^{\text {II }}$ The consensus about the social construction of ethnicity does not mean that ethnicity is defined in the same way by all authors. ${ }^{\mathrm{I} 2} \mathrm{~A}$ typical example of a definition is the one used by Bonacich and Modell. ${ }^{\mathrm{I}}$ They define ethnicity as a communalistic form of social affiliation, arising from a special bond among people of like origins, and disdain for people of dissimilar origin. The definition leaves it open as to what people share. Although it is not clear what is needed to create a separate ethnicity, language and religion feature in all of the definitions. As this article will show, language and religion were not enough for the cohesion of German immigrants.

This article describes the organisations of German immigrants who came to the Netherlands in the Igth century. The focus is on German immigrants in the Dutch town Utrecht. Comparisons are made with German immigrant communities elsewhere, especially in the U.S. What was it that held German immigrants together and set them apart from others? German immigrants in various countries set up similar 
organisations: churches, Liedertafeln (Singing Societies), and Turnvereine (Gymnastic clubs). We take a closer look at these organisations to see how these organisations expressed their Germanness or Deutschtum. Before that, I briefly outline the characteristics of the German immigrant community in Utrecht.

\section{A German Community?}

Since I have described the German immigrant community of Utrecht at some length elsewhere, ${ }^{\mathrm{I}}$ a short summary will suffice. In the igth century, German immigrants formed by far the largest minority in Utrecht (as in the rest of the Netherlands); $60 \%$ of the immigrants was born in German regions. In the middle of the igth century, there were more than 40,000 Germans in the Netherlands. In Utrecht, as in the Netherlands as a whole, German migrants constituted I to I.5\% of the population. In I849, Utrecht had a total population of 50,000. There were three times that number of inhabitants by I920.

The German immigrant communities in the Netherlands were much smaller than those in the United States. At the end of the Igth century, more Germans lived in New York than in Berlin. ${ }^{15}$ In I880, St. Louis had 54,90I German born inhabitants of a total population of $350,5 \mathrm{I} 8$ (I6\%). Cincinnati had a German population of $46, \mathrm{I} 57$ of a total of 255,I39 inhabitants (I8\%) and Milwaukee had 31,483 Germans of a total population of $\mathrm{II}_{5}, 587(27 \%) .{ }^{\mathrm{I} 6}$

Between I850 and 1859, there was a total of 957 German immigrants in Utrecht of whom 535 were men and 422 women (sex ratio I.3). Between I860 and I879, I23I additional immigrants arrived: 747 men and 484 women (sex ratio I.5). On average, German men stayed in Utrecht for a shorter period of time than their female counterparts. Migration to Utrecht mostly consisted of young adults, rather than of families with children.

The German immigrants were not all from the same regions, but some concentrations can be pointed out. ${ }^{17}$ The majority of the German immigrants came from regions that border with the Netherlands. Shopkeepers and shop assistants came from the region around the river Ems, in Oldenburg's Münsterland. These shopkeepers sold textiles and cloth, and were almost all men. The assistants were both men and women, but the former outnumbered the latter. The shopkeepers lived and worked in the city centre, where they had large shops and boarding houses for their assistants. We find these communities of shopkeepers in all of the major Dutch cities. The shopkeepers and their employees formed $20 \%$ of the German immigrant community in Utrecht. Smaller groups (each 5\%) were formed by the filemakers from the 
Ruhr area and stucco-workers from a specific part of Oldenburg; these were all men. Domestic servants mainly came from the region near the German-Dutch border, where the Rhine enters the Netherlands.

Migrants from the Westerwald, in Nassau, formed the largest group within the German immigrant population (30\%). They were traders in stoneware jugs and pitchers. The Westerwalders formed a strong cohesive community. The community had a high intermarriage rate $(85 \%)$. The Westerwalders lived in a few streets where they formed $80 \%$ of the population. The Westerwalder community in Utrecht was essentially a transplanted village, as defined by the American historian Kamphoefner. ${ }^{18}$ Most of the Westerwalders in Utrecht came from two villages: Ransbach and Baumbach. Other Dutch towns had Westerwalder communities that were similar to the one in Utrecht, but the community in Utrecht was particularly large. The Westerwalders in Utrecht also show similarities to Westerwalder communities in the United States. ${ }^{\text {I9 }}$ These communities were alike in their cohesion. They were, however, older than the Utrecht community. In Utrecht, the community dated from the beginning of the I9th century. The Westerwalders that migrated to America sailed on four ships that left the Dutch port of Rotterdam in I740, I744, I749 and I753. The American communities were also transplanted villages, but the Westerwalders that went to America showed a greater diversity including pastors and schoolmasters. In Utrecht, there were only traders. In the American cases not only large parts of a village population were transplanted, as in Utrecht, but also the complete village social network. ${ }^{20}$

\section{Formal Versus Informal Organisations}

Informal organisations may predate formal ones. In her classic I949 article on immigrant organisations, the American sociologist Mary Bosworth Treudley ${ }^{2 \mathrm{I}}$ made the assumption that formal organisations not only arose after the community had existed for long enough to reach some stability, but also that formal institutions became more important as informal ties became weaker. When individuals no longer shared enough common experience and understanding to be bound by informal ties, the immigrant community sought to forge more formal ties so as to retain some form of bonding.

By their nature, informal organisations leave few traces in the archives. As a result, they are difficult to track down. Some individuals did, however, play an important role in the German immigrant society, and can therefore be seen as the key figures in an informal network.

Theodor Engelmann, for instance, played such a role. He came to Utrecht in 1869 and married the daughter of the by that time very fa- 
mous and popular Utrecht professor, F.C. Donders. Engelmann's wife died within one year of the marriage at the birth of their twins. Englemann remarried a German pianist, Emma Vick Brandes. ${ }^{22}$ For the next 20 years the couple regularly organised concerts in their home, which were attended by some 200 people per event. German composers - including Johannes Brahms - musicians and scientists attended these informal gatherings. The events were a meeting point for all those who shared an admiration for German culture, language, and science. Religious and political discussions were taboo.

Similar roles were played by Henry Rahr, Heinrich Geuer, and Johann Kufferath. Rahr was a shopkeeper who sold pianos and sheet music. He also tuned and repaired pianos and as such knew many people. He was an active member of many clubs and societies, and regularly organised concerts. Geuer was a glass painter who set up an organisation which he called the Shelfish [sic] Club, because he missed the evenings full of fun and nonsense he used to enjoy in his native Cologne, and which had been concluded with a traditional meal of haddock (Schellfisch). Johann Kufferath was the city music director, appointed as such by the city government. He was responsible for the city orchestra and music education. In the 40 years that he held his job, he invited countless soloists to perform with the orchestra, and sent orchestra members to Germany to fulfil their professional training.

The American historian Dobbert shows how German pub owners played an important role in the informal German immigrant network. ${ }^{23}$ In the Igth century it was joked that if three Germans migrated to America, the first one opens a pub, so that the other two will have a place to argue. ${ }^{24}$ The pub owner would introduce the newly arrived immigrant to the more settled countrymen. The pub owner would also provide a place for groups of immigrants to meet, combined with the lavish consumption of German beer.

In Utrecht, 35 German immigrants - men and women - owned either a pub or a hotel. The pubs served German beer and had German waiters and staff. Three of the most important hotels were German.

\section{A German Language?}

German immigrants spoke a variety of German dialects. ${ }^{25}$ The Plattdeutsch that was spoken near the German-Dutch border was very different from the dialects that were spoken elsewhere. ${ }^{26}$ The Plattdeutsch of the lower Rhine and Weser was a bit like Dutch, and very different from the melodious Bavarian of the South, or the nasal Saxon of the East. The written German, Schiftdeutsch, was the language of the upper classes: university graduates, higher government officials, teachers, 
noblemen, and commissioned officers. It was the language of Goethe and Schiller. As the historian Dobbert remarks, it was not a living language, since the majority of the immigrants did not speak it. ${ }^{27} \mathrm{Mi}$ grants were taught written German before their migration, but their children grew up in the new country with spoken German only. The language could therefore never be the essence of Deutschtum. This severely limited the range of all organisations that were based on language, such as theatres, schools, and newspapers.

In the beginning of the I9th century Utrecht had a small private German school with 30 pupils. By I850, the school had disappeared. Some of the wealthier German immigrants could employ private instructors or could send their children to boarding schools. There are indications that some German immigrants pursued this tactic. However, neither option was chosen on any large scale. It was not only the language problem that made it difficult to run a school. The rich and the poor, as a rule, did not send their children to the same school. The same was true for Catholics and Protestants. Differences in language, class, and religion made it difficult to set up school. Even in the Dutch city of Rotterdam, which had a much larger and more homogeneous community, attempts to set up a school did not succeed until the end of the igth century. ${ }^{28}$

\section{A German Church?}

A little under half of the German immigrants in Utrecht were Catholic, about the same percentage were Protestant and 2\% were Jewish. About half of the Protestants were Lutheran, and the other half Calvinist. Religious differences were important within the Utrecht population as a whole, as they were in the rest of the Netherlands. Dutch Catholics and Protestants were usually organised in separate associations. The German society was also deeply divided along religious lines. ${ }^{29}$ Thus it is reasonable to expect that the German immigrants in Utrecht were also organised along religious lines.

The number of German Jews in Utrecht was small. They joined Dutch Jewish organisations in Utrecht. They also joined German nonJewish (and non-religious) organisations, such as the singing societies described below. This is remarkable since in the second half of the Igth century, Jews in the Netherlands were usually denied access to gentile social clubs. ${ }^{30}$

In the United States, Catholics in German immigrant communities had their own parishes. In I85 I, in New York, there were approximately 35,000 German-speaking Catholics. They congregated in two Germanlanguage churches. ${ }^{3 \mathrm{I}}$ German Catholics in New York were poor and 
were concentrated in a few neighbourhoods. Although German-speaking Catholics and Irish Catholics lived in the same neighbourhoods, they did not attend the same churches. ${ }^{32}$ The Germans here felt that a loss of language was tantamount to a loss of faith. ${ }^{33}$ Of course, Latin was the language of the liturgy, but for sermons, confessions and hymns it was a possible to choose between Dutch and German.

In Utrecht, there was no Catholic parish that can be labelled German. This can be deduced from Confession records. Confession before Easter was obligatory for Catholics and the registers of those who confessed have been preserved. From these it is clear that the Westerwalders and Münsterlanders attended different churches. They went to the church nearest to where they lived. The Westerwalders and Münsterlanders came from different German regions, they spoke different dialects, and belonged to differed social classes. The Münsterland shopkeepers were amongst the richer inhabitants of Utrecht; the Westerwalders amongst the poorer.

There may also have been another important difference. In St. Louis, Catholics from the Rhineland and Southern Germany were ill-informed concerning church matters and prone to leaving their church. Catholics from the north of Germany were well-informed concerning their religion and were thus more loyal to their church. ${ }^{34}$ Thus a different attitude towards their own religion could also explain why Catholics from the various regions did not congregate together.

The Lutheran community was very different from the Catholic one. The Lutheran immigrants in Utrecht included both men and women, but men far outnumbered women. The result was that all of the women could, if they wanted, marry within their own church, while the men could not. The Lutheran community was characterised by a high intermarriage rate. This made the church very much an organisation for immigrants and not for their offspring.

The Lutheran church in the Netherlands has a long history. German immigrants had been coming to the Netherlands for centuries prior to the nineteenth century. ${ }^{35}$ The number of immigrants was high in the I7th and I8th centuries. Their numbers started to decline at the end of the I8th century. The Lutheran church in the Netherlands during this period was well-organised. ${ }^{36}$ Its members were almost all immigrants and most were German born. Many children and grandchildren of Lutheran immigrants left the Lutheran church and joined the Dutch Calvinist church. This meant that the survival of the Lutheran church depended on new arrivals from German regions.

As time passed, repeated conflicts arose within the Lutheran church about whether the sermon should be in Dutch or in German. The discussions revolved not only around the language to be used during services, but also concerning adaptation to Dutch society. In German 
states, the Lutheran church was much more orthodox than its counterpart in the Netherlands. In German states the church could afford to take this position because the German states were largely religiously homogenous. The civil government supported the dominant religion and vice versa. In the Netherlands, the Lutheran church was a small minority church and could not claim the same support. The more orthodox perspective in the Netherlands was advocated by preachers trained in German regions. To counterbalance this orthodoxy, the training of preachers in the Netherlands was favoured. ${ }^{37}$

After the turbulent period of 1780 to 1787 , when the Prussian army invaded the Netherlands, the Lutheran church wanted to distance itself from the German invaders and its German heritage. ${ }^{38}$ It symbolically broke with its status as an immigrant church and became a Dutch minority church. The breach was stimulated by a sharp decline in new immigrants by I800. In the I9th century, only a very small portion of the Lutheran church members was born in German regions, although they often descended from German parents or grandparents. Most of the new German Lutheran immigrants who came to the Netherlands in the middle of the I9th century decided not to join the Lutheran church. This decision was reinforced by the fact that the sermons and psalms were no longer in German. Considering the long tradition of Lutheran migration to the Netherlands, one would have expected new arrivals to expand their organisational infrastructure. Instead, the newer migrants who arrived in the mid-I $9^{\text {th }}$ century found the infrastructure was no longer very German and was therefore of little attraction to them.

The conflict within the Lutheran church in the Netherlands shows remarkable parallels to conflicts elsewhere. One constant was that language always played a role. The mid-I $9^{\text {th }}$ century Lutheran church in Cincinnati decided to keep German as the church language as long as five church members preferred services in German. ${ }^{39}$ In the Netherlands, the $18^{\text {th }}$-century conflict is usually described as a conflict between established Lutherans and their offspring on the one hand, and new arrivals on the other. In the US, the conflict was seen more as the outcome of differences between the Plattdeutsch-speaking German immigrants from Oldenburg, and the Hochdeutsch-speaking Lutherans from the south. The Lutheran community of Cincinnati circa I830 consisted of Lutherans from Württemberg and Switzerland, later joined by German migrants from Oldenburg. The Plattdeutsch-speaking German immigrants were more orthodox, the Hochdeutsch-speaking Germans more liberal. In the end, the Plattdeutsch-speaking immigrants established their own church where only speakers of their own dialect were welcome. 
In the I9th century in the US, the Lutheran church was seen as 'one of the strongest bulwarks of [...] Deutschtum' ${ }^{40}$ The Lutheran church played a crucial role in some German immigrant communities. Through its schools and its sermons, both in German, the Lutheran church maintained its culture or its coherence within (the Lutheran part of) the German community. However, religious differences meant that it was never one united German community. According to Luebke, Igth-century German immigrants in the US identified themselves primarily as Catholics, Lutherans, Evangelicals, Mennonites, or Methodists, and only secondarily (sometimes only incidentally) as German. ${ }^{4 \mathrm{I}}$ In I890, in Cincinnati there were I2 German Evangelical, 3 Lutheran, 6 Methodist, 4 Presbyterian, 2 United Brethren, and I German Baptist church, and 34 Catholic Parishes. If the Lutheran church was a bulwark of Deutschtum we should ask whose or what Deutschtum that was precisely.

\section{Innere Mission and the Gustav Adolf Stiftung}

The Lutheran church in Utrecht had grown increasingly unattractive for newcomers since the mid-Igth century. New organisations arose that catered to the needs of the most recent German Protestant immigrants. Contrary to the older organisations, these newer organisations had ties to the emerging German State.

In the second half of the I9th century, two new organisations emerged: the Innere Mission [The Inner Mission] and the Gustav Adolf Vereeniging (GAV).$^{42}$ Both organisations, although in a somewhat different manner, did what was called missionary work amongst the German immigrants in the Netherlands. The Innere Mission and the GAV both stepped into the gap that had opened up when the Lutheran church became less German.

The Innere Mission was based in Germany, but it was also active amongst German Protestants outside Germany. The Innere Mission directed its attention mainly at those Germans who perceived their stay in the Netherlands as temporary such as stucco workers and agricultural labourers. The organisation created a link between Protestantism and the new German nationalism. Retaining people for the faith was equated with retaining them for the nation. German migrants were handed brochures by wandering Innere Mission priests (Reiseprediger) with the symbolic title 'Wegweiser zur Heimat' (guide to the homeland). By keeping to their religious beliefs, the immigrants would be able to find their way home and would thus be saved for the nation. Not all of the German immigrants were addressed in this manner, only the Protestants. The wandering Innere Mission priests came regularly to 
Utrecht upon the invitation of the stucco master Herman Abeling, who organised the church services at his own expense and advertised them in the local newspaper. Some 80 people usually attended the services, 40 of whom were stucco workers. The rest were other Germans living in Utrecht, who for many years had not heard a German service.

The GAV was an affiliate of the German Gustav Adolf Stiftung (GAS). The GAV, however, remained independent of the GAS for several reasons. One was the emerging German nationalism, which the GAS wanted to support along with Protestantism. The GAV believed that these were separate issues, noting that 'Christ was not a German'. ${ }^{43}$ The GAV wanted to fortify Protestantism, not a German Volksgeist. In Utrecht, the GAV had between 300 to 400 members. Membership lists have not been preserved, but it is fairly certain that not all of its members were German, although Dutch Calvinists were advised by their own newspapers not to join this organisation. One-fourth of the GAV's funds went to the German parent organisation (GAS). But the GAV found its own course and disassociated itself from the German nationalism that became increasingly stronger in the GAS as the igth century progressed. Some German immigrants in the Netherlands disagreed with this stance and joined the GAS instead.

\section{Liedertafeln}

All of the German immigrant communities had their singing societies or Liedertafeln. In other countries, Liedertafeln managed to unite German immigrants from very different regional and religious backgrounds. According to the American historian Bohlman, singing played a crucial role in the shaping of a German-American identity. ${ }^{44}$

The first Liedertafel in Germany was set up in Berlin in I809. ${ }^{45}$ The Liedertafeln played a role in the movement for a united Germany. In the I840s, they were an alternative to forbidden political organisations. The idea of the Liedertafel was exported to other countries, together with ideas concerning German unity. Exporting the idea, however, implied transforming it. In the Flemish part of Belgium, Liedertafeln were set up to increase Flemish unity, just as the German Liedertafeln were meant to encourage German unity. A stronger Flanders, it was argued, could be created by singing in German, since this implied creating a distance from both France and the Walloon provinces. The Liedertafeln in the German regions, however, perceived their Flemish counterparts as advocates of a greater German empire, which might include Flanders.

In Denmark, Liedertafeln had favoured the union of Schleswig-Holstein with Germany. After Sleswig-Holstein became part of the German Empire, anti-German sympathies in Denmark grew stronger. For 
the Liedertafeln, this meant that they became much more German in nature. In I867, it was decided that only German-born men and their sons could become members of the Liedertafeln and that the official language at meetings would be German. As a reaction to anti-German sympathies, the German immigrants withdrew into their own organisations and made these more exclusively German in nature. ${ }^{46}$

The dilemma of the Liedertafeln concerned what kind of unity they supported: the unity between German immigrants, as was the case in the US and England, or support for a united Germany and a Great German Empire, which might include parts of Denmark, Flanders, or the Netherlands.

The first Liedertafeln in the Netherlands were established in I827. They were led by Germans, used German study materials and sang only German songs. The Liedertafeln differed from the older singing societies in the way its members sang seated at long tables. In the period from I827 to I9I5, some 500 of these singing societies were founded. Between I845 and I9I5, annual Dutch-German singing contests, were held alternately in Cleves and Arnhem. German contestants usually came from the Lower Rhine region, although interest began to wane after I852. A sharp rise in the number of Dutch organisations followed, and the Netherlands organised its own singing contests. The Dutch singing societies were, however, already less German by the mid-Igth century. Contestants were required to perform at least part of their repertoire in Dutch and composers were invited to write new Liedertafelnstyle songs in Dutch. The reason for this was the fear of annexation, which was expressed throughout the second half of the Igth century and especially after the wars of I866 and I870. The fear of annexation was, however, perhaps less important than the fear of being suspected of supporting annexation.

The Dutch Liedertafeln were not exclusively immigrant organisations; there were also numerous non-German singers, including Dutch contestants and immigrants from other countries. In Utrecht, the Liedertafel Aurora was established in 1845 by the Dutchmen, F.C. Kist. The Liedertafel had approximately 500 members. One in five was German. An analysis of the membership lists shows that the singing societies were all-male but open to German immigrants from various religious and regional backgrounds. Members included rich Catholic shopkeepers and their assistants. There were Lutheran, Calvinist, and Jewish members from almost all runs aspects of society. Geuer, founder of the Shelfish Club was a member, as was piano dealer Rahr, city music director Kufferath, two of the most important pub and hotel owners, and the president of the GAV. Lower-class Catholics, however, were totally absent. None of the poorer Westerwalders were members. 
In I849, the second Liedertafel was established in Utrecht. The UMZV (Koninklijke Utrechtse Mannenzangvereeniging) was a singing society with a membership of some 770. Some of the members from Liedertafel Aurora switched to UMZV. Some of the German shopkeepers, who were not yet members of the older organisation, joined the UMZV instead. For the rest, we find a similar mixture as that of the Aurora. Again we find no Westerwalders amongst its members. A third organisation was founded in 1873 , but this one seems to have been short-lived.

If the Liedertafeln shaped a German-Dutch identity, like it had shaped a German-American identity, this was an identity that, in the first place, did not clearly distinguish the Germans from other groups, and secondly, it was not an all-inclusive identity. Singing societies managed to include some parts of the German immigrant community, but by no means all.

\section{Turnvereinen}

Turnvereinen or gymnastic clubs were as characteristic of German immigrant communities as the singing societies were. ${ }^{47}$ The Turnvereinen were founded in the beginning of the igth century. They were regarded as subversive organisations by the German government. After the failed revolution of I848, many Forty-Eighters or Turners, as these revolutionaries called themselves, left for the United States where they founded the German-American Turner Movement and prepared for new revolutions in Germany. In American towns they built exercise halls, the so-called Turnhalle. These were often impressively large buildings, that not only housed the gymnastic club itself, but also theatre clubs, rifle clubs, chess clubs or German language schools. ${ }^{4}$

Utrecht also had its gymnastic clubs, but they did not play the same role as those in England and the US. The reason for this is that the revolutionaries who emigrated from Germany did not go to the Netherlands. With no revolutionaries, the gymnastic clubs were just gymnastic clubs. One German revolutionary did come to the Netherlands, Carl Euler, did indeed set up a Turnverein in Utrecht. This, however, was a general organisation rather than a German club and it had none of the aspirations that the German Vereine had elsewhere. Its members, I53 in total, were mostly students. Euler seems to have run a second, rather informal Turners association. After Euler left Utrecht in I85I, the gymnastic club Kallisteneia was founded to continue the informal group established by Euler. The club had I50 members, but only one was German. Carl Euler did return to Utrecht once, in I854, this time as an advocate for the GAV. 
Mid-Igth century Utrecht had seven gymnastic clubs with a combined membership of several hundred. The clubs all attracted different sectors of society: students, army officers, civilians, and boys. None of the clubs called itself German; no club used the German word Verein in its name. Seven gymnastic clubs was a lot for this relatively small city. With so many gymnastic clubs, there was little need for German immigrants to set up a German organisation of its own.

In Cincinnati, the Turners set up an impressive Turnverein, which non-German children started to join, and since the children of German immigrants no longer spoke or understood German, English became the accepted language. ${ }^{49}$

In St. Louis, the German immigrants were successful in their efforts to get gymnastics on the curriculum of the public schools. The Turnvereine Teachers also became gym teachers in the public schools..$^{50}$ After this period Turnvereine diminished in popularity. The gymnastic clubs were clearly German in inspiration, but after half a century they had lost much of their Deutschtum. The majority of the German immigrant community had from the beginning not supported the political ideas of the original Turners. Catholic German immigrants were advised to stay away from the gymnastic clubs. If the Turnvereine were indeed expressions of Deutschtum it was again, like the Lutheran church, a Deutschtum, which included only a part of the community.

\section{German Unity}

The German immigrant communities in the US had numerous organisations, but were far from united. 'Wherever there are four Germans gathered, they will find five different ideas. ${ }^{5 \mathrm{II}}$ Most organisations did not survive the first generation, despite the effort of German language schools, pub keepers, newspapers, and theatres to keep the Deutschtum alive. The children of German immigrants no longer spoke German. In an attempt to save the lively German culture that once was, albeit distributed over many different organisations, some key figures in the major German-American immigrant communities attempted to arrive at a more united position by finding a common denominator they were sure existed. German communities in America first celebrated German Day in I883 to commemorate the arrival of the first German immigrants in 1683: Pastorius and his Palantines aboard the Concord, the German equivalent of the Mayflower. ${ }^{52}$ Later, this celebration was combined with the anniversary of the battle of Sedan. Neither the original notion, nor the anniversary of the battle of Sedan appealed to all German immigrants. The Forty-Eighters and the Catholics disassociated themselves from the nationalistic and anti-Catholic sentiments that this 
movement was based on. In the end, the common denominator became the struggle against Prohibition, which was seen as a real threat to German identity. German organisations profited from the sale of beer during large gatherings, and Prohibition would eliminate this source of income. In the end, the Deutschtum represented nothing more than a keg of beer.

In Utrecht, the first organisation that presented itself as German, the Deutsche Verein zu Utrecht, was founded in 1897 by recent German immigrants, all Protestant middle-class men. Contrary to the situation in other countries, where the word Verein was used much earlier, this was the first organisation that used this word. The choice of name was not irrelevant. A name can represent a collective identity and through the name a collective identity is shaped. ${ }^{53}$ This new organisation used both Deutsche and Verein in its name. Its aim was to stimulate Germanness, sociability (Geselligkeit) and a love for Germany. Despite its universal claims and its appeal to Deutschtum, this organisation, like the previous ones, only represented one portion of the German immigrant population.

The First World War was a watershed in German-American history. Many German-Americans began to dissociate themselves from their German ancestry. The situation in the Netherlands was different, due to Dutch neutrality during the war. The Germans in the Netherlands set up organisations that supported German-Dutch families who had lost their breadwinners during the war. This was followed by the creation of a memorial for the German prisoners of war who had died in the Netherlands. In the I920s, the first real attempts were made to create more unity. In the I930s, German organisations came under Nazi influence. At that time, unity was achieved by denying the Germanness of some. ${ }^{54}$

\section{Conclusion}

Most of the Igth century witnessed the migrations of Germans, while there was no actual German State. This meant that there were no state initiatives that could shape or hinder immigrant initiatives by, for instance, enforcing homogeneity and coherence. Before the founding of nation-states, sending societies did little to keep in touch with their former residents. On the contrary, prior to I87I, the various German states as a rule did not take back people that had emigrated, even if it was the emigrant's intention to migrate only temporarily. Once people left, they were often refused re-entry. This changed after German unification. 
In contemporary society, migrants are seen, both by the sending and the receiving societies, as still belonging to their country of origin, despite their migration and long-term stays outside their country of birth. This feeling is expressed by the use of the term 'migrant' even for the second or third generation. ${ }^{55}$ This hereditary immigrant status affects the way immigrants and their descendants organise themselves. In the past, immigrant organisations were mostly a first generation phenomenon, which may offer immigrant organisations greater continuity. Government initiatives and the emergence of the nation-state seemed to make the real difference between the situation then and now.

Deutschtum existed in the Igth century, despite the absence of a German State. Germanness was just a multitude of German organisations making various claims on Germanness. There was a sense of identity, but it was not expressed collectively. Germanness, then, existed without a common denominator. When the German national state finally took shape, this had a profound influence on the notion of identity. Boundaries were defined more sharply, but also excluded more people.

The German immigrant community in Utrecht was not a coherent community although claims on coherence were made by some organisations. It could be asked how coherence, or claims on coherence, relates to integration. The German migrants from the Westerwald formed the community with the most coherence and the least integration. It was also the community with the least formal organisations, and Westerwalders also did not participate in more general German organisations. The coherence of the community seems to have curbed the need for formal organisations and at the same time forestalled the integration of this group. Among the other Germans, coherence was less important and formal organisations were relatively open and integration was easier than among the Westerwalders.

The governments of contemporary sending societies set the boundaries within which the immigrant organisations could function. The governments of the sending societies, contrary to past practices, have tried to maintain an influence over their former subjects for a much longer period of time. Meanwhile, the governments of the receiving societies continue to label the children and grandchildren of immigrants as immigrants. These factors when taken together, seem to give immigrant organisations more a sense of continuity. The examples given in this article reveal that claims of a common identity can be made without a consensus on what this identity actually is. The results are the establishment of ephemeral societies that do not survive the first generation. 


\section{Notes}

I Schrover 2002, I35-I82.

2 Olzak and West I99I, 470.

3 Olson I980, I33.

4 Ibidem, II, II4.

5 Breton, I964, I93-205.

6 Roberts and Boldt I979, I03-108.

7 For an extensive discussion see the special issue on immigrant organisation of the Journal of Ethnic and Migration Studies 2005; Schrover and Vermeulen 2005, 823832.

8 Cohen I985, 685, 693.

9 Ibidem, 685, 693 .

IO Marques 200I, 219.

II Barth I969; Verkuyten I999.

I2 Hutchinson and Smith 1996.

I3 Bonacich and Modell I980.

I4 Schrover 2003; Lesger et al. 2002; Schrover 200Ib; Schrover 2002.

I5 Nadel I990.

I6 Olson i980, II.

I7 Schrover 2002, 82-90.

I8 Kamphoefner, I987, 70.

I9 Kunselman Burgert and Jones I989.

20 Tilly I990.

2I Bosworth Treudley I949.

22 Meijler I984, ix-xv.

23 Dobbert I980, 9.

24 McCaffery I996, 53.

25 Schrover 2002, 9I.

26 König I996, 230.

27 Dobbert I980, 60.

28 Henkes 1998.

29 Fleischer 1988, 57 and the supplement: 89-107.

30 Berg et al. I994.

3I Dolan I972, 4I, 354-368, 355 .

32 Ibidem, 359.

33 Ibidem, 360.

34 Olson I980, ІІ8.

35 Rommes 1998; Kuijpers 2005.

36 Ibidem.

37 Ibidem.

38 Ibidem, I96.

39 Grams I995, 79-90; Holzapfel I998.

40 Goldberg I995, II6.

4I Luebke I974, 34-35.

42 Schrover 2002, $150-156$.

43 Translated from the Dutch original, quoted in Schrover 2002, I54.

44 Bohlman I995, 288.

45 Von der Dunk i966, 317-330.

46 Snell I999, I98, 202.

47 Panayi I995; Nadel I990; McCaffery I996; Snell I999.

48 Nadel I990, II9-I20; Nagler, I80-I8I. 
49 Dobbert 1980, 47.

50 Olson I980, I45.

5I Dobbert 1980, 79.

52 Ibidem, 48.

53 Koopmans and Statham I999, 678.

54 Henkes 1998.

55 Anthias 1998, 565, 569 . 